DOI: $10.33067 /$ SE.1.2021.5

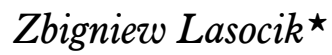

\title{
Defining and Regulating Prostitution from the Polish and European Perspective
}

\begin{abstract}
Prostitution has not received the academic interest it deserves in Poland. On the one hand the issue of eroticism and human sexuality is a relatively strong cultural taboo, on the other research on prostitution raises numerous methodological difficulties. The purpose of this article is to explore two issues. The first is go back to unsatisfactory attempts to define the commercial sex. The second is to look at legal regulations regarding this issue in Poland and several European countries.

At the level of sociological reflection, prostitution can be defined by referring to the elements of a specific interaction between two people, one of whom offers paid sex and the other of whom is interested in using such a service. Prostitution is defined completely differently in law and in several European countries, for example in Great Britain and Austria there are interesting legal provisions. But I propose my own definition of prostitution or sex work in which the eight elements are combined.

As far as legal regulations of prostitution are concern four categories of countries can be mentioned in Europe. From these in which the provision and purchase of sexual services is prohibited, to those where prostitution is legal and the professional status of the person engaging in it is regulated. There is also variety of perceptions of prostitution as a social phenomenon and different typologies of policies implemented by individual countries. But it appears that further studies on sex business and prostitution as a social phenomenon are needed.
\end{abstract}

Keywords: Prostitution, Sex Work, Sex Business, Human Trafficking, Legal Regulations

^ Zbigniew Lasocik - University of Warsaw, e-mail: zlasocik@uw.edu.pl, ORCID: 0000-0002-1921-1073. 


\section{Introduction}

Although it is a surprising observation, prostitution has not received the interest it deserves in Polish scientific literature. This assertion particularly concerns criminological literature, because representatives from other disciplines (usually female investigators and sporadically male representatives) address this issue ${ }^{1}$. A particular feature of recent literature on prostitution is the "intimacy" of scientific research. Published books and articles are almost always in the form of reports on qualitative research usually carried out on very small samples; such publications are often interesting, and rarely unsuccessful. In most cases, it is the authors' intention to try to recreate the profile of individuals providing sexual services, decipher their motivation, or reach the natural environment in which the services are provided (for example, an escort agency). There are also some interesting publications that borderline on autobiography, reporting and fiction. ${ }^{2}$

\section{Why Is Research on Prostitution Difficult?}

The limited interest of criminologists in the issues of sex business, which was mentioned in the introduction, has its origins and consequences. In my opinion, there are two key deterrents. One is social, and the other methodological. In Poland, the issue of eroticism and human sexuality is a relatively strong cultural taboo. This particularly includes institutionalized sex, meaning everything that is associated with the provision of sexual services. Someone who is not a sexologist or doctor, who enters this area as a researcher must be prepared to overcome social barriers. While conducting research on this subject, I experienced reactions ranging from peculiar compassion that he was doing something so "strange" to locker room jokes that were supposed to neutralize the interlocutor's embarrassment. Requests for interviews about prostitution or, more broadly, sex

${ }^{1}$ See, for example, Prostytucja. Studium zjawiska, eds. R. Kowalczyk, M. Leśniak, Kraków 2013; A. Zwoliński, Cyberseks, Kraków 2014; M. Wojciechowska, Agencja towarzyska, (nie)zwykte miejsce pracy, Kraków 2012; I. Ślęzak, Praca kobiet świadczacych ustugi seksualne w agencjach towarzyskich, Łódź 2016; J. Kurzępa, Młodzież pogranicza - „świnki”, czyli o prostytucji nieletnich, Kraków 2005; M. Godzwon, Call girl i video sex chat - praca seksualnie wyzwolonych kobiet czy forma wspótczesnej prostytucji?, Kraków 2010; K. Charkowska, Zjawisko prostytucji w doświadczeniu prostytuujacych się kobiet, Kraków 2012; two studies contained in the volume: Normy, dewiacje $i$ kontrola spoteczna, ed. J. Zamecka, vol. XV, Warsaw 2014; R. Gardian, Zjawisko sponsoringu jako forma prostytucji, Kraków 2010.

2 S. Różycka, Venus bez futra, Wołowiec 2015; D. Dużyńska, Go-Go Club, Gdynia 2015. 
business, and particularly in the context of human trafficking, usually resulted in a defensive response from potential respondents in the form of the reservation: "but I don't know anything about it".

Research on prostitution also raises a second type of difficulties, namely methodological. The world of sex business is a closed world that is inaccessible and defends itself against prying eyes. The social ostracism of individuals providing sexual services and persons using such services means that being a sex worker and being a client is a carefully hidden secret. Researchers are also not on the list of persons who are trusted with this secret. The area of paid sex is protected from being found out also for purely pragmatic reasons, because almost everything that happens there borders on crime. Everyone who has recently conducted research on prostitution has reported difficulties in reaching information sources. ${ }^{3}$ In addition, convincing a person providing sexual services about the good intentions of the researcher and about their reliability is an extremely difficult, if not impossible, task. It is these problems that I wish to devote the following deliberations to.

\section{The Purpose of the Work}

The purpose of this article is to explore two issues. The first is the repeated and unsatisfactory attempts to define the commercial phenomenon of the provision of sexual services. The second is legal regulations regarding commercial sex in Poland and policies implemented by various European countries in this area. Since sexual exploitation is still one of the key forms of modern slavery, both of these areas are very important, both to create a full criminological picture of human trafficking, and to build the foundations of an effective system for eliminating this phenomenon from modern societies.

It should be highlighted at the outset, that in Poland, the provision and purchase of sexual services have been legal since 1998, i.e. since the entry into force of the new Polish Penal Code (1997). ${ }^{4}$ Based on Articles 203 and 204 of the Penal Code, first and foremost, it is prohibited to force others to engage in prostitution, but also to benefit from other people's prostitution, to induce other people to this activity, and to facilitate the paid sex of other people. In other words, Polish regulations allow the provision of sexual services individually, but exclude the existence of places such as brothels. Nevertheless, in practice, such institutions do exist; however, officially they provide escort services or club entertainment. In Poland, all other forms

\footnotetext{
3 See footnote 1.

${ }^{4}$ Polish Penal Code of 6 June 1997 (Polish Journal of Laws No. 88, item 553).
} 
of commercially satisfying the sexual needs of other people, such as erotic dance clubs, massage parlors or peep shows, are also legal.

It is all the more surprising to see the relatively small interest of the criminological community in the problem of prostitution and the abovementioned related phenomena ${ }^{5}$ despite the fact that all of them are at the very center of criminal interest. After all, paid sex is non-standard behavior, and is sometimes treated as a violation of social norms, and yet this is an area of interest to criminologists. On the other hand, prostitution as a social phenomenon is connected in various ways with everything that criminology is most interested in, namely crime, alcohol abuse, drug addiction, pornography and other negative behaviors. Thirdly, the provision of sexual services is an activity in which the economic component is strong, which is becoming increasingly closer to modern criminology. ${ }^{6}$ After all, the essence of paid sex is performing a certain activity (sexual service) in exchange for a financial (or other) benefit, which the parties to the interaction deem to be equivalent. This is the essence of the operation of the market, which is governed by the laws of supply and demand. Finally, if we recognize that criminology is a science aimed at forming a more general reflection on the origins of social order, everything that involves choosing some model to regulate sex business, in particular the sphere of paid sex, seems to be extremely interesting. All the more so because this matter has recently become the subject of strong ideological debate in Poland and Europe, ${ }^{7}$ which I will address further on.

\section{Terminology}

At the beginning, however, I would like to make a note regarding terminology. In Poland, paid sex used to be described with the term "pros-

5 In a sense, an indicative fact is that in the last decade, the best Polish criminological journal, i.e. Archives of Criminology, has featured two studies on this issue, namely: B. Błońska, Wyniki badań terenowych nad zjawiskiem prostytucji w Polsce, "Archives of Criminology", no. XXXIII/2011; J. Derlich-Mielczarek, Zjawisko prostytucji a prawo karne, "Archives of Criminology", no. XXXIII/2011.

${ }^{6}$ On this topic, see, among others: T. Orsagh, Is there a place for economics in criminology and criminal justice? "Journal of Criminal Justice", no. 5/1983; S.D. Levitt, S.J. Dubner, Freakonomics. A Rogue Economist Explores the Hidden Side of Everything, Gliwice 2006.

7 It mainly concerns the opposition between pragmatic thinking that takes into account the subjectivity of individuals providing sexual services, and radical feminism, whose representatives claim that every sex worker, even one who performs this profession voluntarily, is a victim of male dominance. These discrepancies significantly affect the proposed solutions - from decriminalizing prostitution and legalizing the profession, to punishing clients. 
titution", which is relatively strongly inscribed in the Polish language tradition, and its designations do not raise any serious doubts. However, in recent years, scientific literature, journalism and public debate have departed from this term, because in the opinion of many authors, it has negative connotations. ${ }^{8}$ The most popular substitute is "sex work", which is quite a common term in Europe, but in Poland, it is difficult to get the term established in the language of the literature and in colloquial usage. The slightly more descriptive terms that appear in the literature include "provision of sexual services" and "paid sex". These terms will be discussed further on.

The second important term describes the person performing the said profession. Again, in the Polish language, the term used reflexively is "prostitute". The use of this term is even more negated, because while the word "prostitution" refers to a social phenomenon, the word "prostitute" refers to a specific persons and can stigmatize them. This is why the said concept is increasingly being replaced with the term "sex worker". $.9 \mathrm{Al}$ ternatively, these terms can be more elaborate, such as "person providing sexual services" or "person offering paid sex".

Language changes and disagreements over specific concepts both have a strong cultural context. I learnt about this in the first half of 2019, when I was in the United States, where I conducted research on the effectiveness of systems for eliminating human trafficking in various social and cultural contexts. One of the observations I made was about terminology, although this is my initial observation, because I am only at the stage of working through the material collected. I got the impression that the current disagreement in Europe about the language used to describe the provision and purchase of sexual services is invisible in the US. It is quite common for

8 The debate on this topic is ongoing. Different positions result from the adoption of different initial assumptions, different ideologies and methodological issues regarding, for example, the scope of concepts. For more on this topic, see, among others, The Etymology of the terms 'Sex Work' and 'Sex Worker', http://www.bayswan. org/sexwork-oed.html (access 19.11.2019); M. Farley, Prostitution, Trafficking, and Cultural Amnesia: What We Must Not Know in Order To Keep the Business of Sexual Exploitation Running Smoothly, "Yale Journal of Law and Feminism", no. 1/2006; K. Banyard, The dangers of rebranding prostitution as 'sex work', “The Guardian”, June 7, 2016, https://www.theguardian.com/lifeandstyle/2016/jun/06/prostitution-sex-work-pimpstate-kat-banyard-decriminalisation (access 19.11.2019).

9 M. Zdanowska, Lepsze jutro dla pracownic i pracowników seksualnych, "Kontakt" November 17, 2019, https://magazynkontakt.pl/lepsze-jutro-dla-pracownic-i-pracownikow-seciuknych/ (access 17.12.2019); P. Mączewski, I. Szumen, Polscy pracownicy seksualni zdradzaja, jak wyglada ich zawód, ile zarabiaja $i$ czego potrzebuja, "Vice" March 8, 2017, https://www.vice.com/pl/article/nz5zw7/polscy-pracownicy-seksualnizdradzaja-jak-wyglada-ich-zawod-ile-zarabiaja-i-czego-potrzebuja (access 19.11.2019). 
prostitution to be negated as a morally reprehensible and socially harmful phenomenon; however, I did not meet anyone who objected to the use of the term "prostitution" in any way. On the other hand, use of the term "sex work" promoted in Europe caused fairly severe negative reactions. My interlocutors pointed out that combining something as noble and socially important as work with something as unequivocally negative and widely condemned as paid sex is unacceptable. Of course, I also met people who thought differently; however, negative reactions dominated.

In contrast, the European disagreement regarding the concepts of prostitution/prostitute and sex work/sex worker is not only intense, but also takes place on several levels, such as the stigmatizing function of certain words, language tradition and human sensitivity. ${ }^{10}$ However, these issues are beyond the main thread of my considerations, and I do not wish to delve into them too deeply. On the other hand, due to the purpose of this article, there is one important matter that has substantive and practical significance - the scope of specific terms.

Not questioning the need for language evolution, I would like to note that the traditional terms "prostitution" and "prostitute", as well as new language phrases such as "sex work", "sex worker", "sexual service" or "person offering paid sex" are not synonymous. Therefore, the word "prostitute" means a person involved in prostitution or a person undertaking activities aimed at the commercial satisfaction of the sexual needs of others. It can also be said that a prostitute is a person who performs a specific profession. From this perspective, such a person can be called a sex worker. However, there are several other forms of human activity that also pursue the same objective, namely meeting the sexual needs of others in exchange for benefits, that are not prostitution. Examples include erotic massage and erotic dance, or so-called cybersex, which involves simulating or actually performing sex acts in front of a computer camera. ${ }^{11} \mathrm{At}$ the level of initial intuition, but also on the basis of existing knowledge, it can be said that persons performing all the above-mentioned activities can be considered as sex workers, but it certainly cannot be said that they are prostitutes. At the level of self-identification, an erotic dancer who does not have sex with her viewers, and even more so a model working in an erotic services computer studio would with great difficulty accept such a classification of her. It is therefore obvious that the more neutral term "sex worker" is quite broad, as it covers all ways of meeting the sexual

${ }^{10}$ Understanding Sex Work in an Open Society, Open Society Foundation, Last Update April 2019, https://www.opensocietyfoundations.org/explainers/understandingsex-work-open-society (access 19.11.2019).

${ }^{11}$ Cf. A. Zwoliński, op. cit. 
needs of others. ${ }^{12}$ Therefore, every prostitute is a sex worker, but not every sex worker is a prostitute.

\section{Defining Prostitution}

Here, I would like to return to attempts to define prostitution as a social phenomenon that can take place on various levels and in various dimensions. Most commonly discussed are the sociological and legal definitions, which I will address, while the psychological, sexological, anthropological or ethnological terms will not be examined.

Therefore, at the level of sociological reflection, prostitution can be defined by referring to the elements of a specific interaction between two people, one of whom offers paid sex and the other of whom is interested in using such a service. Already since the 1930s, there has been agreement that such a basic constitutive element of prostitution is the direct exchange of sexual services between two people for money and accompanied by mutual emotional indifference. It is also added that this interaction takes place with many clients the choice of whom the person providing the sexual services has little say in. ${ }^{13}$

Prostitution is defined completely differently in law. ${ }^{14}$ Depending on the needs, the legal definition of prostitution can be used to define the area of penalization of certain behaviors, or to indicate what activities in the sphere of sexual behavior are legally permissible. Because Polish legislation lacks such a definition, I decided to use the regulations of other countries. Two European countries - Great Britain and Austria - have interesting legal provisions.

Similarly to Poland, in the United Kingdom, prostitution is legal; however, it is illegal to induce other people to prostitute themselves and to benefit from someone else's prostitution. As far as the definition is concerned, it should be sought in the Sexual Offences Act 2003 of November $20,2003 .{ }^{15}$ British lawmakers used a very interesting strategy, namely, first they defined the profession involving the provision of sexual services (the word "prostitute" is used in the act), and then stated that the phenomenon of providing such services (in the act: "prostitution") should be interpreted in accordance with this definition.

${ }^{12}$ Ch. Harcourt, B. Donovan, The many faces of sex work, "Sexually Transmitted Infections", no. 3/2005, DOI: https://doi.org/10.1136/sti.2004.012468.

13 K. Davis, The Sociology of Prostitution, "American Sociological Review", no. $5 / 1937$, p. $744 \mathrm{ff}$.

14 Prostitution: An International Handbook on Trends, Problems, and Policies, ed. N.J. Davis, Westport 1993.

15 See: https://www.legislation.gov.uk/ukpga/2003/42/contents (access 22.11.2019). 
Pursuant to interpretative rule No. $51^{16}$ referring to Articles $48-50$ of the said act, "«prostitute» means a person (A) who, on at least one occasion and whether or not compelled to do so, offers or provides sexual services to another person in return for payment or a promise of payment to A or a third person". Having such a precise understanding of the term ,prostitute" (I emphasize that this term is used in the act), the British lawmakers propose that the phenomenon of prostitution should be interpreted according to this term: "«prostitution» is to be interpreted accordingly”. To simplify, it can be said that according to British law, "prostitution" is what a "prostitute" does.

The same provision features a second important definition, namely clarification of the term "payment" in British law. Everyone is aware that this is an important element of the sex/business interaction defined here without which the provision of sexual services becomes just a series of erotic adventures or a manifestation of promiscuity. Thus „"payment» means any financial advantage, including the discharge of an obligation to pay or the provision of goods or services (including sexual services) gratuitously or at a discount". Also in this case, the definition is fairly broad, and includes cash payments, as well as all forms of non-cash settlements, including the obligation to provide specific goods or services.

The legal situation of prostitution in Austria differs slightly, because since 1986, people who provide sexual services have been doing it professionally and paying taxes. A distinctive feature of the Austrian model is regulating the issue of paid sex at all possible levels of the administrative structure of the state. Therefore, in accordance with $\int 2(1)$ of the 2011 act regulating the provision of sexual services in Vienna (WPG 2011) ${ }^{17}$ "Prostitution im Sinne dieses Gesetzes ist die gewerbsmäßige Duldung sexueller Handlungen am eigenen Körper oder die gewerbsmäßige Vornahme sexueller Handlungen" "Prostitution within the meaning of this law is the professional acquiescence of sexual acts on one's own body or the commercial performance of sexual acts"18). As can be seen, Austrian lawmakers by referring to the category of "acquiescence" given by a sex worker emphasize the subjectivity of such a person. On the other hand,

16 This is a specific editorial unit of a legal act that contains definitions and interpretative rules unknown to Polish legislative tradition. However, I deliberately omit the issue of the structure of legal acts in Great Britain, because this is a task that requires extensive and in-depth explanations.

17 Gesetz, mit dem die Prostitution in Wien geregelt wird (Wiener Prostitutionsgesetz 2011 - WPG 2011), https://www.wien.gv.at/recht/landesrecht-wien/rechtsvorschriften/html/i4500000.htm (access 7.11.2019).

18 Own translation. 
the said definition highlights the use of one's body for commercial activities, meaning sex activity. If this element was lacking, then other forms of using one's own body to earn money, for example, modeling or entertainment displaying the body without clothing (striptease), ${ }^{19}$ would fall within the definition of so-formulated prostitution.

Now I will attempt to define more precisely what the phenomenon addressed in this article actually is. There is a wealth of definitions in domestic and foreign literature that differ from the legal ones cited above; however, I will not present or analyze them at great length here. ${ }^{20}$ I will present only three attempts in order to show the diversity of approaches to the same phenomenon, as well as how the authors of specific definitions use different narratives. Based on this, I will propose my own definition, which is the result of research on the relationships between prostitution and human trafficking.

I would like to start this short presentation with a definition proposed by one of the most important global institutions - the World Health Organization - which states quite laconically that "sex work is the provision of sexual services for money or goods". ${ }^{21}$ There are only two constitutive elements describing prostitution, namely active behavior in the form of the provision of sexual services and the equivalent provision of services on the part of the recipient. This provision can consist of the transfer of money or other valuable goods. The UN used the term "sex work" rather than ,prostitution" already in 2002.

Fundamentally different language was used by the Polish author of the interwar period - Józef Macko - who in 1927 wrote that the essence of prostitution is "the intercourse of two people that consists not so much of natural sexual selection but on an non-marital consensual contract in which one person gives themselves to another, at a fee, to temporarily satisfy sexual desire". ${ }^{22}$ This is the colorful language of a Catholic social activist, typical of that time, which is difficult to convey even in the best translation. On the other hand, in this definition, almost every word can constitute an inspiration for comment or an excuse for elaborate polem-

19 Cf. the following definitions: https://www.merriam-webster.com/dictionary/striptease; https://www.collinsdictionary.com/dictionary/english/striptease (access 12.11.2019).

20 S. Green, What Counts as Prostitution? "Bergen Journal of Criminal Law and Criminal Justice", no. 1/2016, https://papers.ssrn.com/sol3/papers.cfm?abstract $\mathrm{id}=2801620$ (access 19.11.2019).

${ }^{21}$ Ch. Overs, Sex Work: Part of the Solution. An analysis of HIV prevention programming to prevent HIV transmission during commercial sex in developing countries, WHO 2002, p. 2.

${ }_{22}$ J. Macko, Prostytucja. Nierzqd, handel ,żywym towarem”: pornografja ze stanowiska historji, etyki, higjeny i prawa, Warsaw 1927, p. 4. 
ics. Some phrases, such as "natural sexual selection" and "non-marital consensual contact", even give rise to serious fundamental objections, and only the passage of time lets one gain an appropriate distance.

Finally, there will be an attempt to define the phenomenon in question by a modern expert. Polish sexologist and academic professor Zbigniew Lew-Starowicz claims that prostitution is "various forms of hetero- or homosexual contacts cultivated for commercial purposes with a larger number of people. Prostitution intercourse is treated in terms of material (service) categories and rules out an emotional bond". ${ }^{23}$ It could be said that this is a typical attempt to capture what is most important in the provision of services from the point of view of psychology, sociology and medicine.

By critically analyzing the definitions presented here, getting acquainted with the literature on the topic, and examining the phenomena of the provision of sexual services and human trafficking, ${ }^{24}$ I came to the conclusion that there are a number of constitutive elements that must exist in order to be dealing with sex work (prostitution) as a social phenomenon. That is why I propose that prostitution or sex work can occur when the following elements are combined:

1. the satisfaction of the sexual need of a specific person,

2. the mutual exchange of activities of a purely sexual nature,

3. the interaction of a minimum of two people with clearly defined roles: a person providing a sexual service and a person who is the recipient of such a service,

4. a direct, personal contact between these people,

5. remuneration expressed in money, benefits or services, or in the form of some good, usually a luxury good,

6. a lack of emotional involvement of the person providing the services,

7. a limited ability to have a say in choosing clients,

8. the repeatability of behaviors on the part of the person providing the sexual services.

23 Z. Lew-Starowicz, Stownik seksuologiczny, Warsaw 1986, p. 70.

${ }^{24}$ In 2017-2018, the Human Trafficking Studies Centre of the University of Warsaw participated in the implementation of the Project DESIrE - Demand for sexual exploitation in Europe. This was an international research venture financed by the European Commission, aimed at examining the impact of legal solutions regarding prostitution on the phenomenon of human trafficking. The project was implemented by an international consortium that also included Vrije Universiteit Brussel (Belgium), Tilburg University (the Netherlands), Uppsala University (Sweden), and the organization FLIGHT in Croatia. As part of the studies, researchers also interviewed people providing sexual services. 
The article will now take a closer look at each of these elements.

First of all, it should be emphasized that underlying prostitution as a social phenomenon is the need to satisfy the sexual desire of a potential client. In this case, one of the key rules of market economy is useful, according to which demand determines supply and, therefore, if there are people who need specific services, such services appear. This claim contradicts the increasingly often expressed belief that the opposite is true - that the growing number of people offering sexual services is causing the number of people interested in purchasing them to increase. ${ }^{25}$ In addition, there are authors who are of the view that the expansion of sex business leads directly to an increase in the scale of human trafficking. ${ }^{26}$ This is why public debate on prostitution partly takes the form of deliberations on whether and to what extent one can influence demand, i.e. reduce it in practice, usually by reaching for criminal law and restrictive regulations regarding the provision of services - this does not say much about education.

The second constitutive element of sex work is the mutual exchange of sexual activities between a minimum of two people who are in direct and personal contact with one another. I will show two examples of how important all these elements are. The first can be erotic massage, which in its pure form means that only the masseuse is active, and so even if there is sexual gratification, the activities involved are not of mutual nature. It is similar with the use of so-called "phone sex" services. In this case, it is a phone call that can satisfy sexual needs. Here, too, there can be an interaction of two people who are in direct contact because they are talking to each other, just that it is not personal contact.

In line with the rules of market economy, the amount of remuneration for a service is determined on the market, which means that the parties treat their services as equivalent. ${ }^{27}$ Usually, this remuneration takes the form of a specific amount transferred directly to the person providing the service or the person who organizes the provision of such services. This does not mean that payment for the service cannot take the form of any non-financial benefit (for example, a service) or in-kind benefit, for example, luxury goods. ${ }^{28}$

${ }^{25}$ L. Smith, S.H. Vardaman, The Problem of Demand in Combating Sex Trafficking, "Revue Internationale de Droit Penal", no. 3/2010.

26 S.-Y. Cho, A. Dreher, E. Neumayer, Does Legalized Prostitution Increase Human Trafficking?, "World Development”, no. 41/2012; S.-Y. Cho, Evaluating Policies Against Human Trafficking Worldwide: An Overview and Review of the 3P Index, "Journal of Human Trafficking", no. 1/2015.

27 Ł. Węgrzynowski, Ekwiwalentność świadczeń w umowie wzajemnej, Warsaw 2011.

28 Over a decade ago, a specific category of people providing sexual services appeared in Poland, called „mall girls”, i.e. female elementary school students aged 
Many definitions of prostitution highlight the lack of emotional involvement of the person providing the sexual services. It should be added that this is a lack of involvement as an average feature of a typical interaction. As is clear from the accounts of women working in sex business, ${ }^{29}$ there are situations in which such involvement occurs, and sometimes it is even in the form of sympathy. On the other hand, there is a certain fraction of people providing sexual services who do not do this only for the material benefits, but also to meet their own sexual needs or as a result of complicated emotional relationships. ${ }^{30}$ In their case, minimal emotional involvement is a condition for achieving the intended objective both in the purely physiological and emotional spheres.

As regards the possibility of choosing clients, the matter is slightly more complicated. If someone provides sexual services as part of an organized business (brothel, escort agency), they must accept the rules in this regard at the given institution. If the institution allows a small margin of acceptable deviation from the principle that every client is accommodated, the employee must accept this rule or leave. On the other hand, self-employed individuals have more to say in this matter, as they can decide for themselves, although the scope of this freedom is superficial. It is well known that people who engage in prostitution (usually women) do not do this because they are looking for unlimited sexual contacts but make such a difficult decision because they are in a tough financial situation or in a complicated personal situation. ${ }^{31}$ It can therefore reasonably be said that excessive "pickiness" in terms of client selection limits income and is therefore contrary to the principles of effective operation, including in a purely economic dimension.

And finally, there is the matter of repetition. There can only be talk of prostitution when the offering and performing of sexual services is a repetitive activity. At the same time, the frequency of such an activity must be such that it can be considered the dominant element of such an individual's life, which means that it is a key source of income. This, in turn, means that cases of wom-

12-15 years who satisfied the sexual needs of men in shopping malls in exchange for luxury goods, mainly clothing and cosmetics. The phenomenon was so common that it became a source of inspiration for the creators of the feature film called „Mall Girls" directed by Katarzyna Rosłaniec, Poland 2009. See also: https://www.polityka. pl/tygodnikpolityka/klasykipolityki/1800410,1,kim-sa-polskie-galerianki.read (access 13.11.2019).

29 Interviews conducted as part of the above-mentioned DESIrE research project.

30 K.J. Renner, Seduction, Prostitution, and the Control of Female Desire in Popular Antebellum Fiction, "Nineteenth-Century Literature", no. 2/2010.

${ }^{31}$ B.M. Hobson, Uneasy Virtue: The Politics of Prostitution and the American Reform Tradition, New York 1987, p. 85 ff. 
en who, for example, occasionally make sexual contact with men, sometimes charge some money for it, and sometimes, for example, go on attractive trips abroad, would have to be excluded from the area of prostitution. ${ }^{32}$

\section{Legal Regulations of Prostitution - European Experience}

The phenomenon of providing sexual services cannot remain unregulated by government. International and European standards leave a wide range of freedom in choosing the optimal model for regulating prostitution and shaping proper practice in the area of satisfying the demand for sexual services. The decision to recognize paid sex as a crime is a purely political matter, and quite a sensitive one at the same time, because it is part of a special area - human sexuality. The key problem here comes down to the question of: is the provision of a paid sexual service by person $A$ and the purchase of such a service by person $B$ a private or public matter? If this question were to be asked differently, it would be: if and to what extent is the described interaction covered by permissible state intervention? Or perhaps it should be excluded from such intervention? If two people with formal and emotional ties (spouses) or only emotional ties (lovers) interact in a sexual manner, there is no doubt that this is a purely private relationship and no state intervention can come into play. But does such certainty exist when person ' $A$ ' enters the market with the offer of sexual services, and offers them so effectively that the information reaches a potential client who is ready to buy the service offered and pay the set price? In such a situation, it can be reasonably argued that the sexual interaction that takes place to some extent loses its purely private, intimate nature, and becomes an element of the functioning of the market that, even to a minimal extent, but nevertheless, is subject to government regulation. ${ }^{33}$ Moreover, it becomes the subject of legal protection like any other contract, even in terms of the reliability of the parties to the contract or the equivalence of benefits. I highlight these issues, but I will not elaborate on them, because this is not the subject of my interest.

However, I would like to focus on a matter much closer to the interests of criminology, namely the issue of safety. In this dimension, the question

32 Such women are sometimes referred to as luxury call girls, sugar baby or sponsees, cf. on this subject, for example, http://party.pl/newsy/oliwia-misiak-dzchłopna-dowynajecia-sugarbaby-kim-jest-jak-zyje-31793-r3/; http://blog.sugardaters.pl/2017/10/04/ sugar-advisor-sugar-jak-narkotyk/ (access 5.11.2019).

33 For extremely interesting considerations on this topic, see, among others: A.E. Aldridge, M. Zakowski, Rynek, Warsaw 2006, p. 28 ff. 
of fundamental importance is: if, and if so, to what extent does the state take responsibility for the safety of individuals participating in commercial sexual interactions? Does a person providing sexual services have the right to expect that legal solutions and the practice of the functioning of public institutions will guarantee their minimum safety? For example, to the extent that is necessary so that they do not fall victim to human trafficking. Of course, they are protected just like any other person within the jurisdiction of the state, but I am more concerned about whether they are subject to special protection given their profession. It is also about forcing such a person to do what they do (human trafficking), unauthorized reaping of the benefits of their prostitution by third parties (pimps), and about negative behavior by clients. The client may, for example, exceed the scope of the contract when it comes to its subject (sexual acts), but also may not fulfill the voluntary financial obligations they accepted. ${ }^{34}$ On the other hand, it is also about the safety of the client, who may become a victim of some form of dishonesty on the part of the sex worker, or the subject of an attack by individuals associated with the process of the provision of sexual services (pimp, security guard). For a lawyer, the described situations do not raise any doubts, as the general principles of law apply. Where the behavior of a particular person exhausts the constitutive elements of a crime, mechanisms of criminal law are triggered, and where there is unreliability, civil (sometimes administrative) law may enter the scene. However, this does not solve the problem, as the variable that very strongly disturbs this clear picture is the nature of the provision, and quite special circumstances.

Although sexual desire is one of the most important human needs, the activities aimed at satisfying it are very much a cultural, social, and even moral taboo. Showing sex in public, for example, on television, no longer offends anyone, but talking about private sexual experiences is still seen as inappropriate. On the other hand, in societies such as Poland, prostitution has not yet obtained sufficiently clear social acceptance, and is treated as something shameful. Such circumstances may generate situations in which the negative behavior of one of the partners (participants) of paid sex may be left without the proper reaction from the other partner. For example, neither an abused woman nor a deceived client will report this to the police. This will usually be due to shame arising from the nature of the relationship, and less often due to fear of the consequences. However, irrespective of what caused such behavior, it naturally leads to a lack of response from state institutions. This, in turn, can lead to the buildup of

\footnotetext{
${ }^{34}$ I omit the case of violence, which seems obvious.
} 
negative emotions that are needed by neither the participants of the interaction, nor by any "healthy" society.

Some practical problems are also related to the issue of where the provision of sexual services and promotion of such offers should take place. In private apartments, the streets, specially prepared places, or designated city quarters? Moreover, one should ask whether appropriate regulations should be left to state or local authorities. Is it possible to unambiguously advertise what services a specific person or institution provides? These seem to be socially relevant questions; however, readiness to provide clear answers is not seen always and everywhere. If one were to assume that the provision and purchase of sexual services is a purely private sphere, the chance of getting any response is drastically reduced. It is not so if it was to also be recognized as a public sphere. Either way, it must be remembered that in the background, there is always the danger of human trafficking and the need to protect victims.

Due to the length of this article, I will not elaborate on this topic. I will end by simply signaling this thread, which, despite its importance, has been quite effectively overlooked in public debate to date. However, this important issue became the subject of reflection and was a key thread in the above-mentioned research project DESIrE - Demand for sexual exploitation in Europe. ${ }^{35}$ Various aspects of the dilemma mentioned here have been the subject of analyses and empirical studies that already are but will also be the subject of separate publications. ${ }^{36}$

Here, I will simply state that when it comes to regulating the issue of the provision and purchase of sexual services, following the DESIrE project on the map of Europe, four categories of countries can be highlighted, each of which corresponds to a different regulatory model. The first is one in which the provision and purchase of sexual services is prohibited by criminal law; in the second, prostitution is legal but the purchase of sexual services is prohibited and punished; the third model provides that individual prostitution is legal, but all organized forms are not, and it is forbidden to benefit from other people's prostitution; and finally, in the fourth model, prostitution is legal and the professional status of the person engaging in it is regulated..$^{37} \mathrm{I}$ will attempt a brief characterization of these models.

35 See footnote 24 on this topic.

${ }^{36}$ Handbook on demand in the context of human trafficking for sexual exploitation, DESIrE, https://project-desire.eu/wp-content/uploads/2019/01/A5_Desire2018_09.pdf (access 8.11.2019).

${ }^{37}$ L. Reinschmidt, Prostitution in Europe between regulation and prohibition. Comparing legal situations and effects, "Working Paper", No. 13, Observatory for Sociopolitical Developments in Europe 2016. 
In countries in the first group (A), prostitution is illegal under criminal law (offense) or misdemeanor law (administrative tort). The provision of sexual services is usually considered a minor violation of law that is associated with relatively mild penalties, usually without deprivation of liberty. On the other hand, profiting from someone else's prostitution (pimping) or many forms of organizing the prostitution of others are considered serious crimes, particularly if it is a repeated offense for the perpetrators, or if they used violence. There are 17 countries in Europe that have implemented this model of regulation of prostitution. These include Albania, Andorra, Belarus, Croatia, Montenegro, Denmark, Estonia, Finland, Kosovo, Liechtenstein, Lithuania, Moldova, Russia, San Marino, Serbia, Ukraine, and Vatican City.

The second system in which prostitution is legal and the prohibition covers the purchase of sexual services is sometimes referred to as the "Swedish model", as Sweden was the first country in which this system was introduced (1999). The matter is quite difficult to explain, as at first glance, such a solution seems unreasonable: being a sex worker and providing services is legal, but being a client is not?! If one were to look at the matter from an economic point of view, the situation looks like this: there is a legal product on the market - in this case a sexual service - but this product cannot be purchased because it is prohibited by law. This political and legal structure is founded on the assumption that prostitution (including voluntary prostitution) is always an unacceptable form of gender-based violence leading to serious harm to individuals and to society as a whole. This model has been introduced in five European countries (Group B): Sweden, Norway, Iceland, Ireland and France.

The system of legal prostitution has two pillars; the first is the consent to the individual provision of sexual services, and the second is the lack of consent to all forms of organized prostitution and profiting from the prostitution of others. A typical example of how this model functions in practice, are the solutions adopted in Poland. As has already been mentioned, in accordance with the provisions of the Polish Penal Code, it is prohibited to force anyone to provide sexual services, to induce another person to do so, or to help anyone in this regard. The purchase of sexual services does not result in any negative effects, provided that it does not violate other regulations, for example, those prohibiting the use of violence or using the services of persons under a certain age limit. In addition to Poland, this system works in 16 European countries: Bosnia and Herzegovina, Belgium, Bulgaria, Cyprus, the Czech Republic, Spain, Luxembourg, Macedonia, Malta, Monaco, Portugal, Romania, Slovakia, Slovenia, Great Britain, and Italy (group C). 
Finally, there is the second mutation of the system of legal prostitution, which is characterized by the legalization of the profession of the provision of sexual services. A person engaged in this profession does so legally in the sense that their business is registered and their income is taxable. On the other hand, there are also different systems and different customs for registering those engaged in prostitution. What is important from the point of view of protecting the interests of migrant workers is the fairly common requirement of these systems to obtain a work permit for foreigners. In Europe, this model has been introduced in eight countries: Austria, Greece, the Netherlands, Latvia, Germany, Switzerland, Turkey, and Hungary (group D).

\section{Perception of Prostitution as a Social Phenomenon}

This is what the case looks like from a purely legal perspective. Now, it is time to shed more light on the social aspects. When one analyzes the history of the sociology of sex work, it is clear that this profession has been described in several ways, including: 1 . as one of the typical deviant behaviors; 2 . as a specific profession performed by a specific group of women; 3. as one of the forms of domination of men over women (genderbased perspective) and 4 . as a multidimensional social phenomenon with a complicated etiology. ${ }^{38}$ In this situation, criminologists would gladly add another perspective, namely that derived from C. Lombroso, who argued that prostitution, which is a negative consequence of the intense eroticism of women, is a kind of equivalent to male crime. ${ }^{39}$ Let's now briefly present the positions.

The first approach, which is dominated by the belief that prostitution is pathological in nature, strongly corresponds to the traditional belief that sex should only occur in the context of marriage, and that the sale of sexual services must be treated as antisocial behavior. First of all because it violates all standards of correct (moral) behavior but can also lead to the spread of dangerous diseases. If any actions were taken to eliminate prostitution, they were motivated by religious, ideological and medical reasons.

Prostitution seen as a profession has nothing in it that would not allow one to view this behavior as a form of the exchange of equivalent benefits. It is obvious that sex work improves the socio-economic status of the per-

38 R. Weitzer, Sociology of Sex Work, “Annual Review of Sociology”, no. 35/2009, p. 214.

39 O. Pollak, The Criminality of Women, Philadelphia 1950, p. 90; C. Lombroso, G. Ferrero, The female offender, New York 1898, p. 147 ff. 
son performing it, satisfies a key social need, and in practice provides greater control over working conditions than many "traditional" professions do. From this perspective, sex workers perform very similar social functions to nurses or physiotherapists.

The growing role of feminist thought in shaping views on social phenomena has resulted in prostitution being described as the effect of male dominance and female submission in general, and particularly in the sexual activity sector. In this perspective, sex workers are seen as "objects" of exploitation and violence, which are constitutive elements of the relationship described here. Therefore, as a result, any act of buying a sexual service, even between adults who consent to it, is a violation of the human rights of the person selling the service.

In the approach that here can have the working name of a multi-dimensional approach, it is assumed that prostitution is a complicated social phenomenon. It is made up of various references, activities, relationships and individual experiences, of which only some may be harmful to persons providing sexual services or may be seen as deviant. There is certainly a risk of human trafficking and exploitation, but there is also a real threat of violence. On the other hand, one cannot limit sex work to exploitation, or reduce the experiences of someone engaging in this work to a feeling of slavery and trauma. Such a polymorphic analysis of prostitution ${ }^{40}$ should definitely have a place for these negative phenomena, but other ones such as job satisfaction, a decent income or confirmation of one's own attractiveness cannot be ignored. ${ }^{41}$

Properly defining paid sex as a social phenomenon, but above all answering the question of whether it poses a threat to the existence of a society, has serious consequences in terms of political decisions. If sex work is perceived as a deviance that is harmful to society, radical measures should be applied, mainly including criminal law. Two models can be derived from this way of thinking, and they have been described above; one of them boils down to the criminalization of prostitution, and the other to punishing buyers of sexual services (country groups A and B). On the other hand, if sex work is perceived as a multidimensional, complex phenomenon that is a form of gainful activity of specific groups, the approach of the authorities should be dominated by thinking about effective regulation of this industry, for example, by means of labor law, and by a focus on ensuring the safety of persons providing sexual services, or support in situations where such people decide to change their lifestyle and take

${ }^{40}$ R. Weitzer, op. cit., p. 215.

41 A source of interesting deliberations on this subject is a sex worker blog, the content of which can be found at https://escortgirl.blog/ (access 7.11.2019). 
up another job. Two models are closer to this approach; in these models, prostitution is legal and is either considered a profession with all the consequences of this or is lawful on an individual level and all forms of exploitation of someone else's prostitution (groups $\mathrm{C}$ and $\mathrm{D}$ ) are penalized.

Such a classification of legal regimes is quite widely criticized, as the way in which individual countries treat sex work is usually incoherent and inconsistent, and practice is often not aligned with the law. ${ }^{42}$ This is why the typology of policies implemented by individual countries proposed by P. Östergren should be treated as a very interesting attempt to go beyond these limitations. Based on empirical data, the above-mentioned author proposed three models of socio-political response to the phenomenon of sex work, namely the restrictive model, the repressive model and the integrative model. ${ }^{43}$

The model known as repressive is founded on the belief that prostitution is a negative social phenomenon. It is not that the provision of sexual services is harmful to the person who does it, but above all that it is dangerous for all of society. It could be said that it is evil in itself. This is why the purpose of state authorities must be to completely eliminate the paid sex sector by using repressive measures, mainly criminal law. The prohibition may apply to the provision of services, their purchase, or both, as well as all to activities in between, for example, brokering. Thus, several variants of the situation are possible: only the sex worker is an offender, only the client is an offender, or both the sex worker and the client are offenders. Irrespective of these determinations, so-called third parties that mediate in the trade of services or otherwise organize them are also criminally liable. As offenders, individuals who provide sexual services are not entitled to any benefits, and their work is not covered by state protection. ${ }^{4}$

Underlying the so-called restrictive policy is also the belief that sex work is pathological in nature and that it has negative effects, although the argument of "public health" may be more common. Here, the state's strategy of action is to a lesser extent derived from ideology, while the authorities, when undertaking certain measures, follow a pragmatic approach to a much greater extent. Of course, they use criminal law and administrative law to regulate the functioning of sex business; however,

${ }^{42}$ E. Bernstein, L. Shaffner, Regulating Sex: The Politics of Intimacy and Identity, New York/London 2005; H. Wagenaar, H. Amesberger, S. Altink, Designing Prostitution Policy: Intention and Reality in Regulating the Sex Trade, Bristol/Chicago 2017.

${ }^{43}$ P. Östergren, From Zero-Tolerance to Full Integration: Rethinking Prostitution Policies, "Demand AT Working Paper”, no. 10/2017.

${ }^{44}$ Ibidem, p. $13 \mathrm{ff}$. 
usually by influencing the conditions in which services are provided. If there are criminal sanctions, they usually relate to pimping or brokering, or it may be prohibited to offer services outside designated municipal zones or to violate restrictive regulations on the licensing of sex work, or the obligation to register or undergo sanitary inspection. ${ }^{45}$

In the model that the above-mentioned author defines as integrative, the provision of sexual services is perceived as a multidimensional social phenomenon that contains negative elements but is not devoid of positive factors. The most important thing, however, is that the integrative model is built based on respect for human rights. Sex workers are treated like everyone else who provides services, except that, unlike everyone else, they are stigmatized and exposed to relatively high risk in their line of work. Integrative policy therefore strives to integrate the sex services sector with other social, economic and legal structures. The most important instruments of influence in this case are labor law and social law. On the other hand, the authorities' objective is to reduce the stigmatization of workers providing sexual services, minimize their marginalization, improve working conditions, provide different forms of support, and create favorable conditions for changing professions. ${ }^{46}$

\section{Conclusions}

The inaccessibility of the world of sex business means that the literature on the topic is modest and focuses on phenomena that are more accessible, such as street prostitution, or on the activity of female sex workers. The natural result of this is a slightly distorted picture of reality that does not include individual organizers of sex business, male clients, male employees, female clients, transsexual people and larger structures (criminal groups) involved in running brothels. A completely forgotten area of scientific exploration is sexual behaviors other than prostitution, the purpose of which is to meet the needs of another person ${ }^{47}$ Examples of such behaviors are erotic massage, peep shows, webcams and erotic dance such as lap dancing. ${ }^{48}$ Similarly, good criminological and sociological research on the pornographic industry and other forms of showing erotica are limited. ${ }^{49} \mathrm{I}$ am

45 Ibidem, p. $14 \mathrm{ff}$.

${ }^{46}$ Ibidem, p. $15 \mathrm{ff}$.

47 A search of the available materials prepared for the DESIrE project shows that this issue is rarely addressed, and in some cases not at all.

${ }^{48}$ Lap dance is literally "a dance on the lap", and it means a type of club entertainment consisting of teasing a man's erogenous zones by a nude or semi-nude dancer.

49 R. Weizer, op. cit., p. 230. 
convinced that further studies on such specific sex business sectors combined with analyses of prostitution regulation systems will help to discern the various dimensions and aspects of sex work. This, in turn, will bring a better diagnosis of sexual exploitation and human trafficking closer.

\section{References}

Aldridge A.E., Żakowski M., Rynek, Sic!, Warsaw 2006.

Banyard K., The dangers of rebranding prostitution as 'sex work', "The Guardian", June 7, 2016, https://www.theguardian.com/lifeandstyle/2016/ jun/06/prostitution-sex-work-pimp-state-kat-banyard-decriminalisation (access 19.11.2019).

Bernstein E., Shaffner L., Regulating Sex: The Politics of Intimacy and Identity, Routledge, New York/London 2005.

Błońska B., Wyniki badań terenowych nad zjawiskiem prostytucji w Polsce, "Archives of Criminology", no. XXXIII/2011.

Charkowska K., Zjawisko prostytucji w doświadczeniu prostytuujacych się kobiet, Impuls, Kraków 2012.

Cho S.-Y., Dreher A., Neumayer E., Does Legalized Prostitution Increase Human Trafficking?, "World Development", no. 41/2012, DOI: https:// doi.org/10.2139/ssrn.1986065.

Cho S.-Y., Evaluating Policies Against Human Trafficking Worldwide: An Overview and Review of the 3P Index, "Journal of Human Trafficking", no. $1 / 2015$.

Davis K., The Sociology of Prostitution, "American Sociological Review", no. 5/1937, DOI: https://doi.org/10.2307/2083827.

Derlich-Mielczarek J., Zjawisko prostytucji a prawo karne, "Archives of Criminology", no. XXXIII/2011.

DESIrE Project, https://project-desire.eu/wp-content/uploads/2019/01/ A5_Desire2018_09.pdf (access 8.11.2019).

Dużyńska D., Go-Go Club, Novae Res, Gdynia 2015.

Farley M., Prostitution, Trafficking, and Cultural Amnesia: What We Must Not Know in Order To Keep the Business of Sexual Exploitation Running Smoothly, "Yale Journal of Law and Feminism", no. 1/2006.

Galerianki, movie directed by Katarzyna Rosłaniec, Poland 2009.

Gardian R., Zjawisko sponsoringu jako forma prostytucji kobiecej, Impuls, Kraków 2010.

Gesetz, mit dem die Prostitution in Wien geregelt wird (Wiener Prostitutionsgesetz 2011 - WPG 2011), https://www.wien.gv.at/recht/landesre cht-wien/rechtsvorschriften/html/i4500000.htm (access 7.11.2019). 
Godzwon M., Call girl $i$ video sex chat - praca seksualnie wyzwolonych kobiet czy forma wspótczesnej prostytucji?, Impuls, Kraków 2010.

Harcourt Ch., Donovan B., The many faces of sex work, "Sexually Transmitted Infections", no. 81/2005, DOI: https://doi.org/10.1136/sti.2004.012468.

Hobson B.M., Uneasy Virtue: The Politics of Prostitution and the American Reform Tradition, Basic Books Inc, New York 1987.

http://blog.sugardaters.pl/2017/10/04/sugar-advisor-sugar-jak-narkotyk (access 5.11.2019).

http://party.pl/newsy/oliwia-misiak-dzchłopna-do-wynajecia-sugarbabykim-jest-jak-zyje-31793-r3 (access 5.11.2019).

http://www.bayswan.org/sexwork-oed.html (access 19.11.2019).

https://escortgirl.blog (access 7.11.2019).

https://papers.ssrn.com/sol3/papers.cfm?abstract_id $=2801620$ (access 19.11.2019).

https://www.collinsdictionary.com/dictionary/english/striptease (access 12.11.2019).

https://www.legislation.gov.uk/ukpga/2003/42/contents (access 22.11.2019). https://www.merriam-webster.com/dictionary/striptease (access 12.11.2019). https://www.polityka.pl/tygodnikpolityka/klasykipolityki/1800410, 1,kim-sa-polskie-galerianki.read (access 13.11.2019).

Kurzępa J., Młodzież pogranicza - „świnki”, czyli o prostytucji nieletnich, Impuls, Kraków 2005.

Levitt S.D., Dubner S.J., Freakonomics. A Rogue Economist Explores the Hidden Side of Everything, HELION, Gliwice 2006.

Lew-Starowicz Z., Stownik seksuologiczny, Agencja Omnipress Warsaw 1986.

Lombroso C., Ferrero G., The female offender, D. Appleton and Company, New York 1898.

Macko J., Prostytucja. Nierzad, handel „żywym towarem”: pornografja ze stanowiska historji, etyki, higjeny i prawa, Polski Komitet Walki z Handlem Kobietami i Dziećmi, Warsaw 1927.

Mączewski P., Szumen I., Polscy pracownicy seksualni zdradzaja, jak wyglada ich zawód, ile zarabiaja i czego potrzebuja, "Vice", March 8, 2017, https://www. vice.com/pl/article/nz5zw7/polscy-pracownicy-seksualni-zdradzaja-jakwyglada-ich-zawod-ile-zarabiaja-i-czego-potrzebuja (access 19.11.2019).

Orsagh T., Is there a place for economics in criminology and criminal justice?, "Journal of Criminal Justice", no. 5/1983, DOI: https://doi.org/10.1016/ 0047-2352(83)90024-7.

Östergren P., From Zero-Tolerance to Full Integration: Rethinking Prostitution Policies, "Demand AT Working Paper", no. 10/2017.

Pollak O., The Criminality of Women, University of Pennsylvania Press, Philadelphia 1950. 
Prostitution: An International Handbook on Trends, Problems, and Policies, ed. Davis N.J., Greenwood Publishing Group, Westport 1993.

Prostytucja. Studium zjawiska, eds. Kowalczyk R., Leśniak M., Oficyna Wydawnicza AFM, Kraków 2013.

Reinschmidt L., Prostitution in Europe between regulation and prohibition. Comparing legal situations and effects, "Working Paper", no. 13, Observatory for Sociopolitical Developments in Europe 2016.

Renner K.J., Seduction, Prostitution, and the Control of Female Desire in Popular Antebellum Fiction, "Nineteenth-Century Literature", no. 2/2010, DOI: https://doi.org/10.1525/ncl.2010.65.2.166.

Różycka S., Venus bez futra, Wydawnictwo Czarne, Wołowiec 2015.

Ślęzak L., Praca kobiet świadczacych ustugi seksualne w agencjach towarzyskich, Wydawnictwo Uniwersytetu Łódzkiego, Łódź 2016.

Smith L., Vardaman S.H., The Problem of Demand in Combating Sex Trafficking, "Revue Internationale de Droit Penal", no. 3/2010, DOI: https://doi.org/10.3917/ridp.813.0607.

Understanding Sex Work in an Open Society, Open Society Foundation, Last Update April 2019, https://www.opensocietyfoundations.org/explainers/understanding-sex-work-open-society (access 19.11.2019).

Ustawa z 6 czerwca 1997 roku - kodeks karny, Dz.U. 2017 poz. 2204.

Wagenaar H., Amesberger H., Altink S., Designing Prostitution Policy: Intention and Reality in Regulating the Sex Trade, Policy Press, Bristol/Chicago 2017, https://doi.org/10.26530/OAPEN_627654.

Węgrzynowski Ł., Ekwiwalentność świadczeń w umowie wzajemnej, Wolters Kluwer, Warsaw 2011.

Weitzer R., Sociology of Sex Work, "Annual Review of Sociology", no. 35/2009, DOI: https://doi.org/10.1146/annurev-soc-070308-120025.

Wojciechowska M., Agencja towarzyska, (nie)zwykte miejsce pracy, NOMOS, Kraków 2012.

Zamecka J., Normy, dewiacje i kontrola spoteczna, vol. XV, IPSiR UW, Warsaw 2014, DOI: https://doi.org/10.31338/uw.9788323514657.

Zdanowska M., Lepsze jutro dla pracownic i pracowników seksualnych, "Kontakt", November 17, 2019, https://magazynkontakt.pl/lepsze-jutro-dlapracownic-i-pracownikow-seciuknych/ (access 17.12.2019).

Zwoliński A., Cyberseks, PETRUS, Kraków 2014. 